\title{
Improvement of mechanical behaviour of cylinder head alloys
}

\author{
Christian Kliemt ${ }^{1, \mathrm{a}}$, Franz Wilhelm² and Joachim Hammer ${ }^{2}$ \\ ${ }^{1}$ IABG mbH, Einsteinstrasse 20, 85521 Ottobrunn, Germany \\ ${ }^{2}$ LWM, University of Applied Sciences, Seyboth Str. 2, 93053 Regensburg, Germany
}

Cylinder heads of combustion engines are exposed to complex loading conditions in service. With respect to the efforts made in terms of carbon reduction and fuel consumption these parts were continuously optimized in numerous research projects during the last two decades [1-6]. Additional efficiency increase is directly related to improved high temperature material performance. Besides the development of new lightweight alloys detailed knowledge about the specific mechanical behaviour at elevated temperatures is essential for advances in design and lifetimes under service conditions. In particular, the interaction of complex thermal and mechanical forces under service loading is one of the major factors affecting the lifetime [7].

In this paper the thermo-mechanical fatigue (TMF) behaviour of three cast AlSiMg alloys with small modifications of the chemical composition is investigated under out-of-phase uni-axial loading according to [8]. In detail the Si was modified, while the Magnesium content was kept nearly constant. The alloys were heat treated according to T6 representing maximum precipitation hardening. The results are compared to TMF data of the alloy AlSi6Cu4 representing a standard as this alloy is used in service. The heat treated state was also T6. TMF tests $(\mathrm{R}=1)$ were performed on solid cylindrical specimens in air in a temperature range between $200-400{ }^{\circ} \mathrm{C}$. Strain amplitudes from $0.2 \%$ to $0.7 \%$ were applied. The heating and cooling rate was $5 \mathrm{~K} / \mathrm{s}$ in all cases.

For identical experimental TMF conditions, e.g. constant strain amplitudes, temperature range and heating rates the developing stress amplitudes are consistently higher as the $\mathrm{Si}$ content is increased. As for all AlSiMg alloys investigated almost identical contributions of precipitation hardening can be presumed, the hardening effect due to the Si content is evident. In contrast the fatigue life clearly increases with decreasing $\mathrm{Si}$ content as the Si-phase in the eutectic act as crack initiation sites. It is shown that the coarseness and angularity of Si increase with the silicon content.

The hysteresis loops for the AlSiMg are all flatter compared to the reference $\mathrm{AlSi} 6 \mathrm{Cu} 4$ and the major deviation is among the $\mathrm{AlSiMg}$ types and the $\mathrm{AlSi} 6 \mathrm{Cu} 4$ reference, indicating that the change from $\mathrm{Cu}$ to $\mathrm{Mg}$ is more significant than the variations in the Si content. For OP TMF loading, the shortest lifetimes were exhibited by the highest Si content and the longest for the lowest Si content at both low and high strain amplitudes, Fig. 1.

\footnotetext{
${ }^{a}$ Corresponding author: kliemt@iabg.de
}

This is an Open Access article distributed under the terms of the Creative Commons Attribution License 4.0, which permits unrestricted use, distribution, and reproduction in any medium, provided the original work is properly cited. 


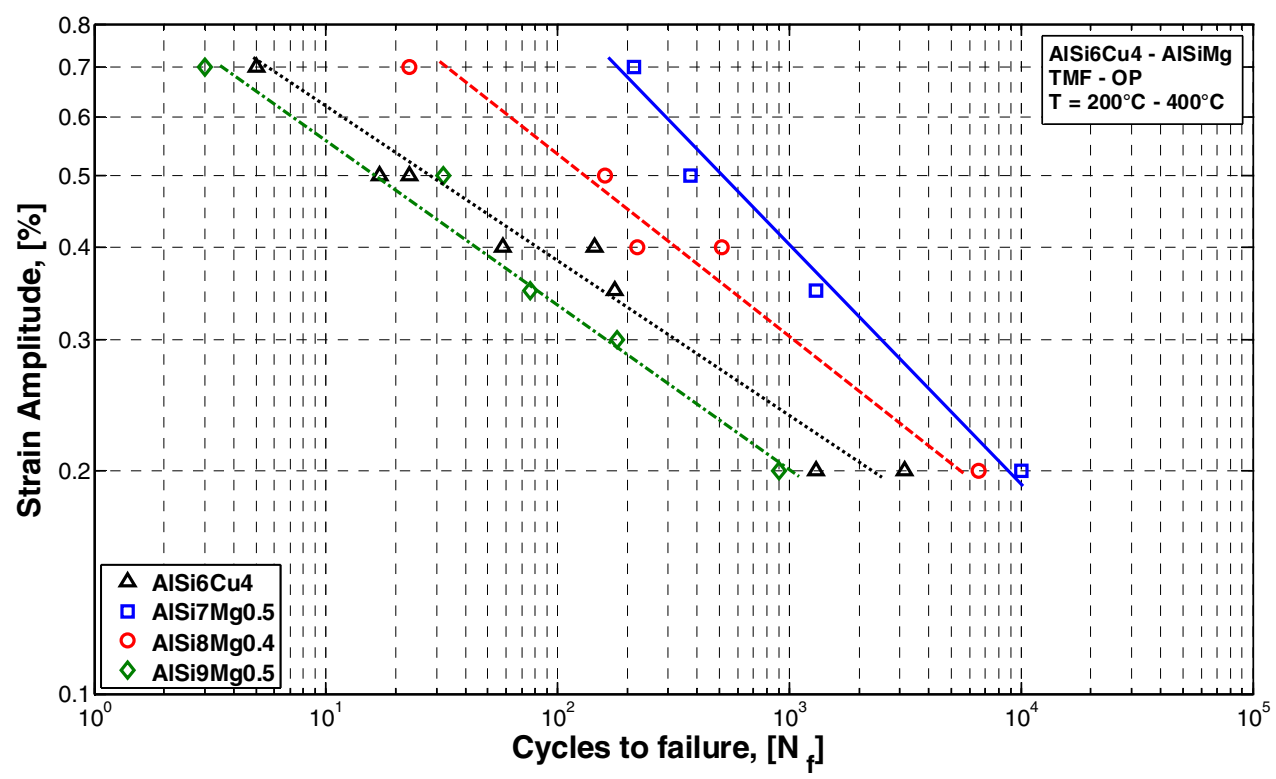

Figure 1. Relation between strain amplitude and cycles to failure for AlSi6Cu4 and AlSiMg alloys under OP-TMF loading (triangle $=\mathrm{A} 1 \mathrm{Si} 6 \mathrm{Cu} 4$, square $=\mathrm{AlSi} 7 \mathrm{Mg0.5}$, circle $=\mathrm{AlSi} 8 \mathrm{Mg} 0.4$, diamond $=\mathrm{AlSi} 9 \mathrm{Mg} 0.5$ ).

\section{References}

[1] F. Achatz, J. Fröschl, and S. Rödling, Innovative Testing Concept of Cylinder Heads, MTZ, vol. 70, no. 12, pp. 34-38, 2009

[2] F. Achatz, J. Fröschl, and S. Rödling, Zeitgeraffte und kostenoptimierte Bauteilprüfung an Zylinderköpfen, Materials Testing, vol. 52, no. 7-8, pp. 502-507, 2010

[3] F. Achatz, J. Fröschl, S. Rödling et al., Zeitgerafft und kostenoptimierte Betriebsfestigkeitsuntersuchungen an Zylinderköpfen auf einem thermischen Zylinderkopfprüfstand, DVM Betriebsfestigkeit, vol. 136, pp. 191-200, 2009

[4] J. Bergmann, and W. Schütz, Auswirkung des Heissisostatischenpressens auf die Festigkeitseigenschaften von Aluminium A357, in DVM Betriebsfestigkeit: "Moderne Fertigungstechnologien, 1991

[5] F. Wilhelm, J. Spachtholz, M. Wagner et al., Simulation of the Viscoplastic Material Behaviour of Cast Aluminium Alloys due to Thermal-Mechanical Loading, Materials Science and Engineering, vol. A \& B, 2014

[6] T. Bischoff, S. Rödling, and B. Stauder, Innovative Prüfmethodik zur Ermittlung der thermomechanischen Ermüdung an Zylinderköpfen, Materials Testing, vol. 54, no. 10, pp. 655662,2012

[7] C. Kliemt, R. Reuben, and J. Hammer, The influence of temperature on the lifetime behaviour of an AlSiCu alloy under low cycle fatigue conditions, in 16th International Colloquium on the Mechanical Fatigue of Metals, Brno, 2012

[8] P. Hähner, E. Affeldt, T. Beck et al., Validated Code of Practice for Strain-Controlled ThermoMechanical Fatigue Testing, Institute for Energy, Petten, 2006 